\title{
Language Composition and Cultural Characteristics of Mandailing Onang-Onang Charactersas A Relevance of Indonesian Language Learning In Smk Negeri 3 Kota Padangsidimpuan
}

\author{
Dedi Zulkarnain Pulungan \\ \{pulungandedi@gmail.com\} \\ Lecturer Indonesian Language and Literature Education FKIP UGN, J1. Kampus I Bukit Tor \\ Simarsayang, Padangsidimpuan 22712, Indonesia
}

\begin{abstract}
Onang-onang song is a poem that is sung when manortor (dancing) at a traditional Mandailing wedding ceremony that will be applied to learning Indonesian language and literature. The lyrics of the song onang-onang are sung by paronang-onang (singer) when suhut (party owner), namora pule (bride), anak boru, mora, and kahanggi dance (manortor). This song has texts on the values of local wisdom (1) divine values (2) the value of cooperation and sincere cooperation (3) the value of harmony, and (4) the aesthetic value. This study aims to explain the linguistic composition of the onang-onang songs and local wisdom in them based on a systemic functional linguistic review. This research was conducted in the city of Padangsidimpuan. The method used is a qualitative method with a descriptive analytical approach. The method used is a qualitative method with a descriptive analytical approach. The stages of text analysis using note-taking techniques include collecting data by recording, then grouping, then arranged according to the type and value of what has been selected and presented by providing analysis then drawing final conclusions. The results of the study concluded that in general the twenty onang-onang songs contained a modulation type of disclosure or realization, namely as much as 112 or $60.87 \%$. In contrast to that, the type of modality modality has a smaller number of disclosers, namely 72 or $39.14 \%$. This is due to the subjective modulation modality. In other words, storytellers provide more personal opinion to the readers.
\end{abstract}

Keywords: Linguistic Composition, Mandailing Cultural Characteristics, OnangOnang Song, Relevance of Indonesian Language Learning

\section{Introduction}

Marriage in Batak customs Mandailing has its own characteristics, having a ritual or ceremony traditional Onang-onang Song the time of the wedding. Tribal wedding culture Loaded Mandailing Batak literature, both oral literatures. Oral literature takes part great from Mandaling Batak literature. Onang-onang originally came from the word inang e which means "mother". In the story it is said that there was a child who missed his mother and finally called out while singing by saying Onang-onang [1]. Onang-onang's song is a literary work in the form of poetry that contains an outpouring of feelings and is spoken with beautiful tones. The words contained in the lyrics of Nyanyian Onang-onang have the power of advice and teaching about religion, social culture, and there are also prohibitions in life. [2]. The singing of onang-onang 
in big traditional ceremonies (nagodang) is very necessary for coaching, especially the younger generation. The purpose of holding a traditional ceremony is so that the younger generation knows the history, genealogy, customs, and cultural background handed down by their ancestors. [3]

The text of the onang-onang song is used as research data to analyze the language. Talks about lexical, grammatical (grammar) units in text-based learning must be in the form of talks about a language related to the structure of thinking which is the social goal of the text. [4] Data can be categorized as a translational text that is the transition of two languages between the Batak language Mandailing and Indonesian. In her journal, Putri [5] writes that the translated text was created in a different frame of conditions with freer written forms. The same thing is emphasized by Munday [6] that translators must face and overcome problems that are not found in writing text in general. The boundary frame is related to the necessity to align language codes, cultural values, the world and perceptions about it, style and aesthetics, and etc.

In this study, the onang-onang song text is considered important to be studied because the onang-onang song text is one of the poems whose meaning is poorly understood but the ritual of reading the onang-onang song has been so thickly carried out in the Mandailing community. Learning poetry in schools tells the story of the birth of a character who is considered a role model, of course, there are values that should be exemplified from the stories contained in these verses. Therefore, this research is considered interesting because it will make the onang-onang song text as material. in learning Indonesian Language and Literature after discussing the languages.

The linguistic composition and cultural characteristics of the mandailing onang-onang songs were analyzed using the theory and method of Systemic Functional Linguistics (later abbreviated as LFS), namely systems of meaning and other systems that support them (namely systems of form and expression) to realize these meanings. This study is based on two things that distinguish LFS from other linguistic streams, namely (a) language is a social phenomenon that exists as a social semiotic and (b) language is a text that is construal (mutually determining and referring) to the social context. This is what causes the language to be dynamic, always affected by the circumstances, situations and conditions in which the language is used. [7] This is what causes the language to be dynamic, always affected by the circumstances, situations and conditions in which the language is used. Text or discourse according to LFS is limited as a functional language unit in a social context. [8]

Based on the background of the problems that have been stated above, the researcher formulates the problem under study is a study of the composition of the language and the characteristics of the mandailing culture of the onang-onang song as the relevance of learning Indonesian in high school. In general, the purpose of this study is to study and describe the linguistic composition and cultural characteristics of the mandailing onang-onang songs as the relevance of Indonesian language learning in vocational high schools.

The urgency of this research includes six main essentials in every culture that can be found universally, namely (1) the essence of life (2) the essence of human work (3) the nature of the human view of its existence in the time dimension (4) the nature of human relations (5) the relationship humans with their natural surroundings, and (6) human nature with the creator. A person's cultural values influence him to determine the means, tools, and goals available. Cultural values are systems that can be used as guidelines by every member of society, especially in attitudes and behaviour and also become a standard for assessing and observing how individuals and groups act and behave. So, the value system can be considered as a standard norm in people's life. 


\section{Research Methods}

This research was conducted at SMK Negeri 3 Padangsidimpuan City. The data in this study is the composition of the lexical language contained in the onang-onang song, which is a local wisdom of the Mandailing culture. The research method used to answer the problems in this study used qualitative research methods with a descriptive analytical approach [9]. This research and development procedure will use several combinations of development research models, namely the Borg and Gall model and the Dick \& Carey model. Borg and Gall consisted of three stages, namely: 1) Preliminary study stages, 2) Model development stages, 3) Model testing stages [10].

\section{Results and Discussion}

This research was conducted at SMK Negeri 3 Padangsidimpuan City. The data in this study is the composition of the lexical language contained in the onang-onang song, which is a local wisdom of the Mandailing culture. The research method used to answer the problems in this study used qualitative research methods with a descriptive analytical approach [9]. This research and development procedure will use several combinations of development research models, namely the Borg and Gall model and the Dick \& Carey model. Borg and Gall consisted of three stages, namely: 1) Preliminary study stages, 2) Model development stages, 3) Model testing stages [10].

\subsection{Research Result}

After the data was collected and analyzed, two types of modality were found in the onangonang song, namely modulization and modulation, while the modality values found in onangonang poetry were divided into three levels, namely high, medium and low. Following are the levels of occurrence of the modalities in onang-onang statements.

Table 1. Modality Levels of Occurrence in Onang-Onang Chants

\begin{tabular}{lccc}
\hline Onang-Onang Chants & Modalitas Amount & Clause Amount & Result \\
\hline Verse I & 14 & 26 & 1,86 \\
Verse II & 7 & 43 & 6,15 \\
Verse III & 12 & 32 & 2,67 \\
Verse IV & 8 & 27 & 3,38 \\
Verse V & 8 & 19 & 2,38 \\
Verse VI & 14 & 29 & 2,08 \\
Verse VII & 9 & 23 & 2,56 \\
Verse VIII & 14 & 24 & 1,72 \\
Verse IX & 15 & 28 & 1,87 \\
Verse X & 7 & 42 & 6 \\
Verse XI & 4 & 16 & 4 \\
Verse XII & 4 & 35 & 8,75 \\
Verse XIII & 8 & 42 & 5,25 \\
Verse XIV & 8 & 43 & 5,38
\end{tabular}




\begin{tabular}{llccc} 
Verse XV & 9 & 43 & 4,78 \\
Verse XVI & 7 & 26 & 3,72 \\
Verse XVII & 3 & 33 & 11 \\
Verse XVIII & 14 & 33 & 2,35 \\
Verse XIX & 14 & 57 & 4,08 \\
Verse XX & 5 & 79 & 15,8 \\
\hline Amount & 184 & 700 & -
\end{tabular}

The research findings show that in nyanian onang-onang, the type of modulation modulation dominates the use of the modality with disclosure or the realization of the modality as much as 112 or $60.87 \%$ compared to the type of modality that uses disclosure or the realization of the modality as much as 72 or $39.13 \%$. This is assumed to be a cultural reality that tends to provide advice or examples through the stories in it. furthermore, the poet gives a lot of personal consideration or opinion to the listener. This is reinforced by the value of the medium modulation modality that dominates the use of the modality. Example of a clause containing the disclosure of the dominant modality.

a. Anggo lugun da disi madung matobang on nada tardokkn go lugun niba tu anak If you miss this parent, you can't say that you miss your child once again

b. Nada inang da tarsun nasongon lautan miss very deep like the ocean

In clause (1) the poet intends to inform the parents of their children. The modality that the author uses is 'ever'. Clause (2) shows the intention of the parent's longing for the child. The disclosure modality used is 'always'. In other words, poets give a lot of personal consideration or opinion to listeners. Based on the analysis that has been done, it is known that the most dominant modality value used is the medium tendency modality value and the medium tendency modality value.

This data shows that verse I uses the most dominant disclosure or the realization of the modality at 14 or $7.61 \%$. verse II uses a modality disclosure of 7 or $3.81 \%$. verse III uses a modality disclosure of 12 or $6.53 \%$. verses IV and V use a modality disclosure of 8 or $4.35 \%$. verse VI uses a modality disclosure of 14 or $7.61 \%$. verse VII uses a modality disclosure of 9 or $4.90 \%$. verse VIII uses a disclosure of 14 or $7.61 \%$. verse IX uses a modality disclosure of 15 or $8.16 \%$. verse X uses a modality disclosure of 7 or $3.81 \%$. verses XI and XII use a modality disclosure of 4 or $2.18 \%$. verses XIII and XIV use a modality disclosure of 8 or $4.35 \%$. syair XV uses a modality disclosure of 9 or $4.90 \%$. verse XVI uses a modality disclosure of 7 or 3.81 . verse XVII uses a modality disclosure of 3 or $1.63 \%$. verses XVIII and XIX use a modality disclosure of 14 or $7.61 \%$. and verse XX uses a modality disclosure of 5 or $5.72 \%$.

The most dominant use of the disclosure modality or the realization of the modality that is most dominant in the translation of the onang-onang song is the disclosure or the realization of the modality, which is always, will, desire, hope, want which is included in the modulation of medium tendency, namely 68 or $36.96 \%$ compared to the disclosure or realization. other. With this, it can be concluded that the storytellers are more subjective (the speakers express their wishes, hopes, invitations and requests). The level of occurrence of the above modalities can be illustrated in the diagram below. 


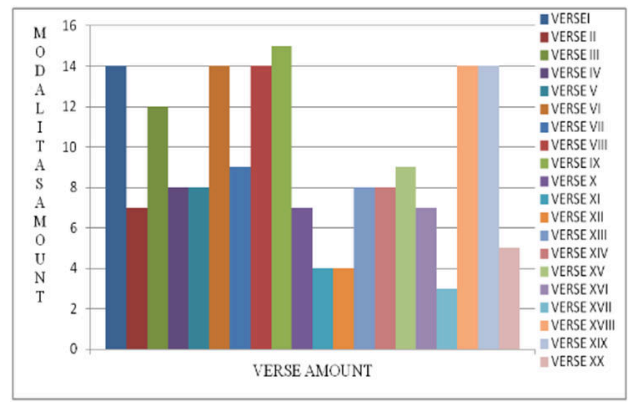

Fig I. The Level of Occurrence the Modalities

\subsection{Discussion}

\section{Language Type of Onang-Onang Song}

Based on the type, the modalities consist of modalization and modulation. modalization consists of probability and frequency whereas modulation consists of necessity and tendency. Modalization occurs from the possibilities with levels of possibility of an activity or activity and the frequency with which an activity or activity occurs frequently. Modulation consists of the necessity with the levels of importance of an activity or activity carried out and a tendency with the levels of one's calling or attachment in his heart to carry out an activity or activity.

The dominant type of modality used in the onang-onang song is the type of modality that uses a disclosure or the realization of the modality as much as 112 or $60.87 \%$ compared to the type of modality that uses disclosure or the realization of the modality as much as 72 or $39.13 \%$. The most dominant use of the disclosure modality or the realization of the modality that is most dominant in the songs of the onang-onang is the disclosure or the realization of the modality which is always, will, desire, hope, want which is included in the modulation of medium tendency, which is 68 or $36.96 \%$ compared to other disclosers or realizations. With this, it can be concluded that the storytellers are more subjective (the speakers express their wishes, hopes, invitations and requests).

The research findings indicate that in onang-onang song, the type of modulation modality dominates the use of the modality. many poets provide personal consideration or opinion to readers in providing advice through the stories in them. This is in line with the opinion of Saragih, the subjective modality shows that personal opinions and considerations of the experience conveyed are carried out by language users who are directly involved in the interaction.

The conclusion above also supports the results of Asriany research which concluded that subjective modulation modalities dominate in providing examples through stories in a story.[11] Khairani concluded that the realization of the modalities used by the author tends to reflect cultural reality the people. [12] Based on the findings, exposure to research results, and supported by existing theories, it is proven that the modulation modality dominates the use of the modality, the onang-onang poets are more subjective (the poet expresses his wishes, hopes, invitations and requests) in giving advice through the stories in the therein. 


\section{The Modality Value of the Onang-Onang Song}

Based on their value, the modalities can be classified into high levels, (i.e. the actions closest to the 'yes' and most likely to occur, low levels, those closest to the 'no' and least likely to occur, and intermediate levels, between levels. high and low. Each of the four types of modality (likelihood, frequency, necessity, and tendency) is divided into three groups based on its intensity or value for practical purposes, namely a high level close to the yes point or the point of activity or activity carried out and a low level close to point not or the point of activity or activity not being carried out. Between the two high and low points there is a midpoint.

The dominant modality value used in the onang-onang statement is the medium modulation modality value, which is 68 or $36.96 \%$ compared to other disclosers or realizations. Many poets provide personal consideration or opinion to listeners in giving advice through the stories in them. This is in line with the opinion of Saragih, the subjective modality shows that personal opinions and considerations of the experience conveyed are carried out by language users who are directly involved in the interaction.

Based on the findings, the exposure of research results, and supported by existing theories, it is proven that the medium modulation modality dominates the use of the modality, the poet's singing is more subjective with the intention, the poet expresses his wishes, hopes, invitations and requests in giving advice through stories that are is inside it.

\section{The Relevance of the Onang-Onang Song Modality in Learning Indonesian in School}

The poetry of the onang-onang song is an example of an exposition text that can be taught to students. One of the linguistic features of the exposition text is modality. Modality learning can provide direct input in developing and improving students' language skills. The same thing was written by Abdurahman in his journal "The study of modalities is an interesting issue and should be discussed for Indonesian speakers who want to be more accurate, precise, and efficient in Indonesian. Learning modalities that are listed in the student textbook only include the modalities of will, have, and must, by using the songs of the students, other modalities are introduced such as the word hopefully, while, always, until, want, and others so as to enrich their insight and said the student's modality in analyzing other texts. [13] Therefore, the ability to speak about the modalities will be richer if it is taught using onan-onang songs.

Based on the results of the questionnaire above, it can be concluded that students are not yet used to using modalities in learning Indonesian in schools. Students more often use the words will, have, must and others as adverbs. This proves that students are not familiar with the naming of modalities. Based on the explanation above, it can be concluded that the modality teaching material, especially the onan-onang song, needs to be taught to students. By using the onangonang song students are introduced to other modalities such as the word hopefully, while, always, until, want, etc. so as to enrich students' insights and word modalities in analyzing other texts

\section{Conclusion}

The results of the study show that, in learning Indonesian in schools, the modalities are in the 2013 curriculum at the level of vocational high school (SMK) Negeri 3 Padangsidimpuan class $\mathrm{X}$ on aspects of linguistic characteristics. The results of this study provide an alternative to be able to strengthen teaching media within the scope of text to students. The use of the onang-onang song text can enrich the insight and vocabulary of the modalities in the quality of the process and the quality of the results in the teaching material. 
In the implementation of learning related to modality in accordance with the nature of the modality and its form, the learning process requires three sequences of activities, namely first, mastering the concept of modality (nature, type and value). Second, applying the use of modalities in a text and third, making criticism and assessments of the use of modalities in the text.

\section{References}

[1] Ritonga, Parlaungan. 2002. Sistem Pertuturan Masyarakat Tapanuli Selatan. Medan:Yandira Agung.

[2] Daulay, Ismail Rahmad. Hasanuddin.Ws dan Manaf. Ngusman Abdul. 2013. Nilai-Nilai Edukatif Dalam Lirik Nyanyian Onang-Onang Pada Acara Pernikahan Suku Batak Angkola Kabupaten Tapanuli Selatanprovinsi Sumatera Utara.Jurnal Bahasa, Sastra dan Pembelajarannya.Vol.1. No. 3

[3] Angriani, Tika. 2016. Pesan yang terdapat dalam Sastra Lisan Onang-Onang Marhorja Manortor (Pesta Pernikahan) di Sungai Pimping Kecamatan Padang Gelugur Kabupaten Pasaman. Padang : STKIP PGRI Sumatera Barat. Skripsi Publish

[4] Mahsun. 2013. Metode Penelitiam Bahasa: Tahapan, Strategi, Metode, dan Tekniknya. Jakarta: Rajagrafindo Persada

[5] Putri, Dian Marisha. 2014. Jurnal Tesis. Pergeseran Bentuk Modalitas pada Film The Raid. USU Institutional Repository.(online).(http://repository.usu.ac.id/h andle/123456789/93893, diakses 21 April 2015.

[6] Munday, Jeremy. Intoducing Translation Studies. Theories and Aplications. London and New York: Roudlege, 2004

[7] Saragih, Amrin. Bahasa dalam Konteks Sosial. Pendekatan Linguistik Fungsional Sistemik terhadap Tata Bahasa dan Wacana. Medan: Program Pascasarjana Unimed. 2006

[8] Halliday, M.A.K. An Introduction to Sistemic Fungsional Linguistics Second Edition. (London: Edward Arnold 2004)

[9] Sukmadinata, Nana Syaodih. Metode Penelitian Pendidikan. Bandung: Remaja Rosdakarya 2012

[10] Trianto, Titik Triwulan Tutik, (ed) . 2014. Mendesain Model Pembelajaran Inovatif, Progresif, dan Kontekstual. Jakarta: Kencana

[11] Asriany, Syifa. Modalitas pada Cerita Rakyat Karo Seri Turi-Turin Karo Dayang Jile-jile Suatu Kajian Fungsional Sistemik. USU Institutional Repository. (online). (http://repository.usu.ac.id/handle/123456789/5771, diakses 20 April 2015.

[12] Khairani, Ita . Modalitas pada Teks Naskah Kaba Minangkabau "Anggun Nan Tungga Si Magek Jabang". Episode: ke Balai Nan Kodo Baha. USU Institutional Repository.(online) (http://repository.usu.ac.id/handle/123456789/18855, diakses 20 April 2015.

[13] Abdurahman. Teori Modalitas sebagai Materi Pembelajaran Bahasa Indonesia. Jurnal Bahasa dan Seni UNP. vol. 2 pp.1-9, 2011 